\title{
Growth and yield of gherkin cultivars in coconut fiber fertigated with nutrient solutions
}

Francisco de A. de Oliveira ${ }^{1}$, Mychelle K. T. de Oliveira ${ }^{1}$, Sandy T. dos Santos ${ }^{1}$, Jessilanne P. B. M. Costa ${ }^{1}$, José F. de Medeiros ${ }^{1} \&$ Lúcia R. de L. Régis ${ }^{1}$

${ }^{1}$ Universidade Federal Rural do Semi-Árido/Departamento de Ciências Agronômicas e Florestais/Programa de Pós-Graduação em Fitotecnia. Mossoró, RN, Brasil. E-mail: thikaoamigao@ufersa.edu.br - (Corresponding author) ORCID: ORCID: 0000-0002-6895-7736; mymykar@gmail.com - 00000003-3264-5172; sandy_thomaz@hotmail.com - ORCID: 0000-0001-6487-555X; jessilannyplinia@hotmail.com; ORCID: 0000-0002-1023-7154; jfmedeir@ufersa.edu.br - ORCID: 0000-0003-1202-8783; luregina13@hotmail.com - ORCID: 0000-0002-5344-9210

\begin{abstract}
Substrate cultivation has been gaining interest from vegetable producers, however technical information for many crops is still recent, such as the gherkin, especially regarding the nutrient solution. This study was developed with the objective of evaluating the performance of three gherkin cultivars (Do Norte, Liso de Calcutá and Liso Gibão) grown in coconut fiber and fertigated with nutrient solutions of different concentrations (50, 75, 100 and $125 \%$ of the recommendation for melon), using a randomized block design, in a $3 \times 4$ factorial scheme, with four repetitions and plots composed of three plants. Growth and production variables were evaluated. In general, cv. Liso de Calcutá produced heavier fruits ( $\left.35.69 \mathrm{~g} \mathrm{fruit}^{-1}\right)$, however $\mathrm{cv}$. Liso Gibão produced an average of 21.6 fruits plant ${ }^{-1}$, being more productive $\left(542.19 \mathrm{~g} \mathrm{planta}^{-1}\right)$. The cultivars Do Norte and Liso de Calcutá were less demanding on nutrients. In order to obtain the highest production of gherkin fruits cultivated in coconut fiber, fertigations must be carried out using nutrient solutions diluted in 50\% for the cultivars Do Norte and Liso de Calcutá, while for cv. Liso Gibão it is recommended to use nutrient solution diluted in $75 \%$ of the concentration of nutrients recommended for the cultivation of melon.
\end{abstract}

Key words: Cucumis anguria L., soilless cultivation, mineral nutrition

\section{Crescimento e produtividade de cultivares de maxixeiro em fibra de coco fertigada com soluções nutritivas}

\begin{abstract}
RESUMO: O cultivo em substrato vem ganhando interesse dos produtores de hortaliças, entretanto ainda são recentes as informações técnicas para muitas culturas, a exemplo do maxixeiro, especialmente quanto à solução nutritiva. Este estudo foi desenvolvido com o objetivo de avaliar o desempenho de três cultivares de maxixeiro (Do Norte, Liso de Calcutá e Liso Gibão) cultivadas em fibra de coco e fertigadas com soluções nutritivas de diferentes concentrações de nutrientes (50, 75, 100 e 125\% da recomendação para o meloeiro), utilizando o delineamento de blocos casualizados, em esquema fatorial $3 \times 4$, com quatro repetições e parcelas constituídas por três plantas. Avaliaram-se variáveis de crescimento e produtividade. De forma geral, a cv. Liso de Calcutá produziu frutos mais pesados $\left(35,69 \mathrm{~g}\right.$ fruto $\left.^{-1}\right)$, contudo a cv. Liso Gibão produziu em média 21,6 frutos planta ${ }^{-1}$ apresentando-se mais produtiva $\left(542,19 \mathrm{~g} \mathrm{planta}^{-1}\right)$. As cultivares Do Norte e Liso de Calcutá são menos exigentes em nutrientes. Para obter o maior rendimento de frutos do maxixeiro cultivado em fibra de coco devem-se realizar as fertigações utilizando soluções nutritivas com $50 \%$ da concentração de nutrientes para as cultivares Do Norte e Liso de Calcutá, enquanto para a cv. Liso Gibão recomenda-se utilizar solução nutritiva com $75 \%$ da concentração de nutrientes recomendada para o cultivo do meloeiro.
\end{abstract}

Palavras-chave: Cucumis anguria L., cultivo sem solo, nutrição mineral 


\section{INTRODUCTION}

The gherkin (Cucumis anguria L.), belonging to the family Cucurbitaceae, is known in the North and Northeast regions of Brazil. It has edible fruits with variations in spiculosity and size, usually with an fruit fresh weight of $30 \mathrm{~g}$ (Silveira et al., 2015) and contain important compounds for health, such as flavonoids, tannins, alkaloids, saponins and steroids that have antioxidant activity (Thiruvengadam \& Chung, 2015).

In recent years, the crop gherkin has been gaining prominence from researchers, mainly in traditional cultivation, evaluating mainly the response to fertilization (Oliveira et al., 2014a) or saline stress (Oliveira et al., 2014b; Souza Neta et al., 2018).

Recently, some researchers have been studying the cultivation of this vegetable in substrate (Oliveira et al., 2012; 2014b); however, more research is still needed to improve the cultivation of this vegetable in this cultivation system. In substrate cultivation, the proper concentration of nutrients in the nutrient solution is a key factor to be successful in this production system, it is of fundamental importance to work with concentrations of nutrients that promote adequate growth and productivity (Portela et al., 2012).

In the literature there are several studies on the concentration of nutrients in nutrient solutions in various vegetables, such as melon (Duarte et al., 2008) and italian zucchini (Strassburger et al., 2011). However, there is little information on the composition and concentration of the nutrient solution for the gherkin grown in substrate, therefore some studies have been carried out using recommended nutritional solutions for other cucurbits, such as melon and cucumber (Oliveira et al., 2012; 2014b).

Given the above, this study was developed with the objective of evaluating the effect of nutrient solutions with different ionic concentrations in the cultivation of gherkin in coconut fiber.

\section{Material ANd Methods}

The experiment was carried outside, from November 2014 to February 2015, in the research sector of the Department of Environmental and Technological Sciences, of the Federal Rural University of the Semi-Arid region, in Mossoró, $\mathrm{RN}$,

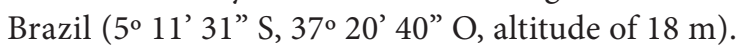

The climate of the region, according to the KöppenGeiger classification, is BSwh' type (hot and dry), having very irregular rainfall, with an annual average of $673,9 \mathrm{~mm}$; average temperature of $27.4^{\circ} \mathrm{C}$, average air relative humidity of $68.9 \%$, average daily sunshine of 7.83 hours and annual sunshine of $2,771.27$ hours and an average wind speed of $0.84 \mathrm{~m} \mathrm{~s}^{-1}$ (Alvares et al., 2013).

During the experiment, climatic data were collected, such as temperature and air relative humidity, using an automatic meteorological station installed at 2,200 $\mathrm{m}$ from the experimental area. The variations recorded throughout the experiment were from 31.4 to $36.7{ }^{\circ} \mathrm{C}$ for maximum temperature; 26.8 to $30.6{ }^{\circ} \mathrm{C}$ for average temperature; 22.2 to $24.6^{\circ} \mathrm{C}$ for minimum temperature; from 42.5 to $79.4 \%$ for air relative humidity and no rainfall was recorded.
The experimental design used was randomized blocks, with treatments arranged in a $3 \times 4$ factorial scheme, with four repetitions, which corresponded to three gherkin cultivars (Do Norte, Liso de Calcutá and Liso Gibão) and four concentrations of nutrients in the nutrient solution $(50,75,100$ and $125 \%$ of the standard nutrient solution recommended for melon). The experimental unit was represented by five vessels with capacity of $10 \mathrm{~L}$, containing $8 \mathrm{~L}$ of coconut fiber.

The cv. Do Norte presents fruits of oval shape with the presence of spikes, average weight of $15 \mathrm{~g}$ and length between 3 and $5 \mathrm{~cm}$ (Feltrin ); cv. Liso de Calcutá has oblong shaped fruits, absence of spicules, average weight of $75 \mathrm{~g}$ and length ranging from 4 to $6 \mathrm{~cm}$ (Feltrin ${ }^{\circ}$ ); cv. Liso Gibão presents fruits of oval shape and absence of spicules, average weight of 40 to $50 \mathrm{~g}$ and average length of $5 \mathrm{~cm}$ (Topseed ${ }^{\circ}$ ).

The $100 \%$ nutrient solution corresponded to the recommended concentration of nutrients for the cultivation of melon in a hydroponic system, with the following formulation, in $\mathrm{g} 1,000 \mathrm{~L}^{-1}$ : calcium nitrate, $900 \mathrm{~g}$; potassium nitrate, $460 \mathrm{~g}$; MAP, $140 \mathrm{~g}$; potassium sulfate, $240 \mathrm{~g}$; magnesium sulfate, $250 \mathrm{~g}$ (Furlani et al., 1999).

All irrigations were performed using nutrient solutions prepared using water collected in the supply system of the UFERSA campus, whose physicochemical analyses demonstrated $\mathrm{pH}=7.5 ; \mathrm{CE}=0.5 \mathrm{dS} \mathrm{m}{ }^{-1} ; \mathrm{Ca}^{2+}=2.0 ; \mathrm{Mg}^{2+}=0.9 ; \mathrm{Na}^{+}=2.8 ;$ $\mathrm{K}^{+}=0.4 ; \mathrm{HCO}_{3}{ }^{-}=0.2 ; \mathrm{CO}_{3}=1.8 ; \mathrm{Cl}^{-}=1.8 ; \mathrm{RAS}=2.32$ mmol $_{\mathrm{c}} \mathrm{L}^{-1}$.

The micronutrients were made available through the addition of a chelated compound (Rexolin BRA Yara) with the following composition: $11.6 \%$ potassium oxide $\left(\mathrm{K}_{2} \mathrm{O}\right)$, $1.28 \%$ sulfur $(\mathrm{S}), 0.86 \%$ magnesium $(\mathrm{Mg}), 2.1 \%$ boron $(\mathrm{B})$, $2.66 \%$ iron $(\mathrm{Fe}), 0.36 \%$ copper $(\mathrm{Cu}), 2.48 \%$ manganese $(\mathrm{Mn})$, $0.036 \%$ molybdenum (Mo), $3.38 \%$ zinc $(\mathrm{Zn})$. The applied dose was according to the manufacturer's indication (30 $\mathrm{g}$ of the compound for 1,000 L of water).

After preparing the solutions, electrical conductivity measurements were carried out, obtaining the following values: $1.43 ; 1.91 ; 2.44$ and $3.11 \mathrm{dS} \mathrm{m}^{-1}$, for concentrations 50, 75, 100 and $125 \%$, respectively. After preparing each nutrient solution, the $\mathrm{pH}$ was regulated to remain in the range of 5.5 to 6.6 with solutions of $0.1 \mathrm{M} \mathrm{KOH}$ and $0.1 \mathrm{M} \mathrm{H}_{2} \mathrm{SO}_{4}$.

The seedlings were formed in polystyrene trays with 128 cells, using substrate formulated by the mixture of coconut fiber and earthworm humus (1:1), being transplanted into the vessels when they presented three to four definitive leaves.

The cultivation was done outside, in order to facilitate the pollination performed by the bees, using the spacing $1.25 \mathrm{x}$ $0.75 \mathrm{~m}$. The useful area was represented by the three central plants, discarding the two plants from the ends of each plot.

The drip irrigation system was applied, using four sets (one for each nutrient solution) formed by a water tank (500 L), a motor pump, flexible polyethylene tubes with a diameter of $16 \mathrm{~mm}$, emitters of the microtubes type (spaghetti) with an average flow of $3.25 \mathrm{~L} \mathrm{~h}^{-1}$.

The volume of applied nutrient solution was defined as the volume required for drainage to occur in the vessels of approximately $10 \%$ of the applied volume, at which point the irrigation was stopped. In all irrigation events, fertilizers were applied, so that each irrigation corresponded to a fertigation. 
The fertigations were performed with variable frequency according to the stage of development of the crop, being controlled with a digital timer, model TE-2163 manufactured by Decorlux ${ }^{\circledast}$, in which the irrigation time was estimated according to drainage observations. Thus, fertigation management was carried out as follows: from transplant to 20 days after transplant (DAT) - six events lasting 5 min each; from 20 to 50 DAT - three fertigations lasting 5 min (7, 9 and 17 hours) and the others lasting $10 \mathrm{~min}$ (11, 13 and 15 hours); from 50 to 80 DAT - two fertigations with duration of $5 \mathrm{~min}$ (7 and 17 hours) and the others with duration of $10 \mathrm{~min}$ (11, 13,15 and 17 hours); 80 DAT until the end of the experiment (110 days) - three fertigations lasting $10 \mathrm{~min}$ (7, 9 and 17 hours) and the rest lasting $15 \mathrm{~min}$ (11, 13 and 15 hours). The volume of solution applied during the experiment was not monitored and the drained solution was not reused.

The plants were conducted vertically, using straps tied to vertical spreaders installed along the planting line. During the experiment, necessary practices were carried out to favor the development of plants, such as: weeding and preventive control of pests and diseases, using pesticides registered for the melon crop.

The harvests were carried out from 60 days after sowing (DAS) until 110 DAS with intervals of 10 days. The fruits were harvested when they had an intense green color and were still immature, up to 20 days after anthesis, because at this stage the fruits are green and tender, presenting soft seeds, which makes them pleasant to the palate. After each harvest the fruits were weighed and dried in an oven to determine the dry matter.

The productivity was determined considering all the fruits of the plant, fruit fresh weight of the fruits was determined by the quotient between the production and the total number of fruits (six harvests).

At the end of the experiment (110 DAT) the plants were collected and evaluated for the following variables: number of leaves, leaf area, dry stem matter, dry leaf matter, dry fruit matter and total dry matter.

To determine the number of leaves, those with leaf blade greater than $5.0 \mathrm{~cm}$ were counted, while the leaf area was determined using the leaf disc method, Eq. 1 (Souza et al., 2012).

$$
\mathrm{LA}=\frac{\mathrm{AD} \cdot \mathrm{DLM}}{\frac{\mathrm{DMLD}}{\mathrm{ND}}}
$$

where:

LA - leaf area, $\mathrm{cm}^{2}$;
$\mathrm{AD}$ - area of the disk, $\mathrm{cm}^{2}$;

DLM - dry matter of leave, g;

DMLD - dry matter of the leaf disc, g; and,

ND - number of discs used in the plot.

To determine the dry matter, the different organs of the plants (stem, leaves and fruits) were packed in paper bags and dried in an oven with forced air circulation at a temperature of $65^{\circ} \mathrm{C}$ for 72 hours.

The data obtained were submitted to analysis of variance by the $\mathrm{F}$ test. In the case of significance, interaction between factors or main factors alone, Tukey's test was performed for the cultivars factor and regression analysis, adjusting to polynomial models for the concentrations factor, using the software for statistical analysis SISVAR (Ferreira, 2014).

\section{Results AND Discussion}

According to the analysis of variance, the interaction between cultivar factors $(\mathrm{C})$ and nutrient solutions (SN) had a significant effect on the variables: number of leaves (NL), leaf area (LA), dry matter of leaves (LDM), stem dry matter (SDM) and total dry matter (TDM) $(\mathrm{p} \leq 0.05)$, as well as on fruit dry matter $(\mathrm{FDM})(\mathrm{p} \leq 0.01)$ (Table 1$)$.

The cultivars Do Norte and Liso de Calcutá showed higher values for the variables NL, LA, LDM and SDM, however cv. Liso de Calcutá did not differ statistically from cv. Liso Gibão for NL, LA and FDM. The cultivars Liso Gibão and Liso de Calcutá showed higher values for the variable FDM, the latter was not significantly different from cv. Do Norte. In addition, it appears that there was no significant difference between cultivars for the variable TDM (Table 2).

Regarding the effect of nutrient solutions on the number of leaves (Figure 1A), it was found that there was no significant effect for the cultivars Do Norte and Liso de Calcutá. These results are partly similar to those presented by Oliveira et al. (2012) working with gherkin, cv. Do Norte, using nutrient solutions with concentrations ranging from 50 to $150 \%$ (Castellane \& Araújo, 1994), in which there was no observed significant response to the number of leaves. However, cv. Liso Gibão showed significant and negative response to the increase in the concentration of nutrients in the nutrient solution, presenting reduction of 215 leaves in the lowest concentration (50\%) to 114 leaves per plant, for the concentration of $125 \%$ (Figure 1A).

Table 1. Summary of analysis of variance and mean values for number of leaves (NL), leaf area (LA), dry matter of leaves (LDM), stem dry matter (SDM), fruit dry matter (FDM) and total dry matter (TDM) in fertigated gherkin cultivars with nutrient solutions of different concentrations

\begin{tabular}{|c|c|c|c|c|c|c|c|}
\hline \multirow{2}{*}{$\begin{array}{l}\text { Sources } \\
\text { of variation }\end{array}$} & \multirow{2}{*}{ DF } & \multicolumn{6}{|c|}{ Mean squares } \\
\hline & & $\mathrm{NL}$ & LA & LDM & SDM & FDM & TDM \\
\hline Cultivars (C) & 2 & $42,496.59 * *$ & $6,833,520 \cdot 36^{\star *}$ & $250.69 * *$ & $340.35^{\star *}$ & $1,450.85^{* *}$ & $4,628.06^{\star *}$ \\
\hline Nutritional solutions (SN) & 3 & $7,805.41^{\star}$ & $6,837,961.62^{* *}$ & $346.64^{\star *}$ & $104.98 *$ & $1,821.47^{* *}$ & $461.55^{\mathrm{ns}}$ \\
\hline $\mathrm{C} \times \mathrm{SN}$ & 6 & $4,967.88^{*}$ & $3,832,053.70^{*}$ & $125.34^{\star}$ & $97.23^{*}$ & $782.61^{* *}$ & $583.61^{*}$ \\
\hline Block & 2 & $599.08^{\mathrm{ns}}$ & $503.990 .41^{\text {ns }}$ & $17.28^{\text {ns }}$ & $121.11^{*}$ & $309.89 \mathrm{~ns}$ & $960.32^{\star}$ \\
\hline Residue & 22 & $1,726.87$ & $592,790.52$ & 19.06 & 23.09 & 149.19 & 172.22 \\
\hline CV & & 19.21 & 19.87 & 15.33 & 17.11 & 20.84 & 16.77 \\
\hline
\end{tabular}

ns - Not significant; ${ }^{*}$ and ${ }^{* *}$ - Significant at $\mathrm{p} \leq 0.05$ and $\mathrm{p} \leq 0.01$, respectively; CV - Coefficient of variation; DF - Degrees of freedom 
Table 2. Average values for number of leaves (NL), leaf area (LA), leaves dry matter (LDM), stem dry matter (SDM), fruit dry matter (FDM) and total dry matter (TDM) in gherkin cultivars fertigated with nutrient solutions of different concentrations

\begin{tabular}{|c|c|c|c|c|c|c|}
\hline Cultivars & NL & LA & LDM & SDM & FDM & TDM \\
\hline Gulitivars & (Unit) & $\left(\mathrm{cm}^{2}\right.$ plant $\left.^{-1}\right)$ & \multicolumn{4}{|c|}{$\left(\mathrm{g}\right.$ plant $\left.^{-1}\right)$} \\
\hline Do Norte & 325.27 a & $4,383.97 \mathrm{a}$ & $29.03 \mathrm{a}$ & $39.60 a b$ & 49.84 b & $118.47 \mathrm{a}$ \\
\hline Liso de Calcutá & $277.58 \mathrm{ab}$ & $3,913.19 a b$ & $30.25 \mathrm{a}$ & $41.85 \mathrm{a}$ & $53.84 a b$ & $125.94 \mathrm{a}$ \\
\hline Liso Gibão & $187.44 \mathrm{~b}$ & $3,435.55 \mathrm{~b}$ & $23.53 \mathrm{~b}$ & $36.86 \mathrm{~b}$ & $67.03 \mathrm{a}$ & $127.42 \mathrm{a}$ \\
\hline
\end{tabular}

Means followed by the same letter in the column do not differ significantly by the Tukey test at $\mathrm{p} \leq 0.05$

A.

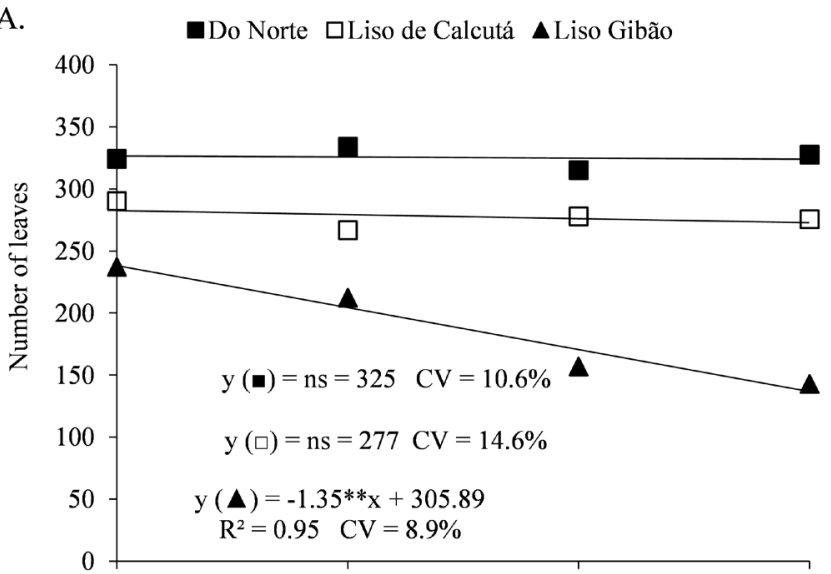

C.

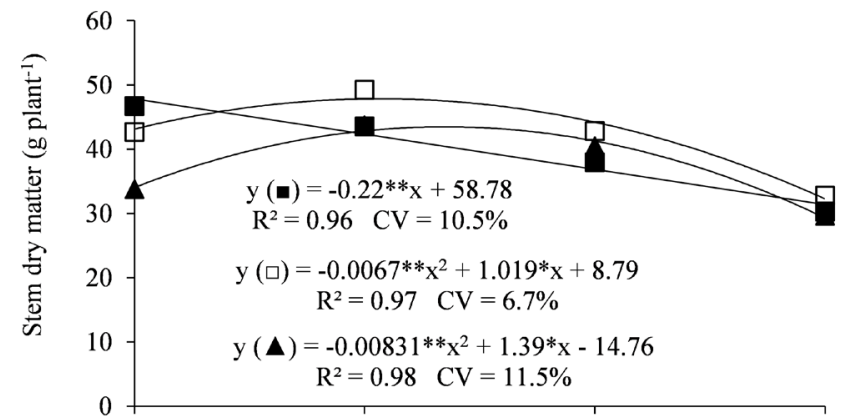

E.

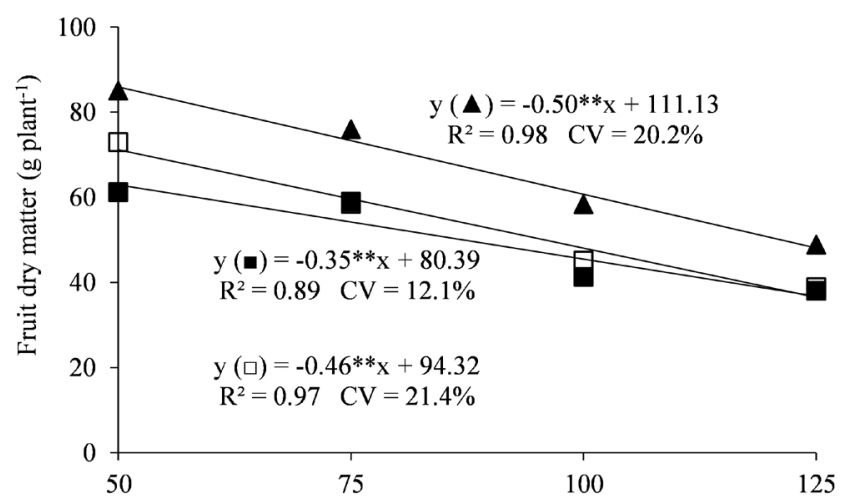

B.

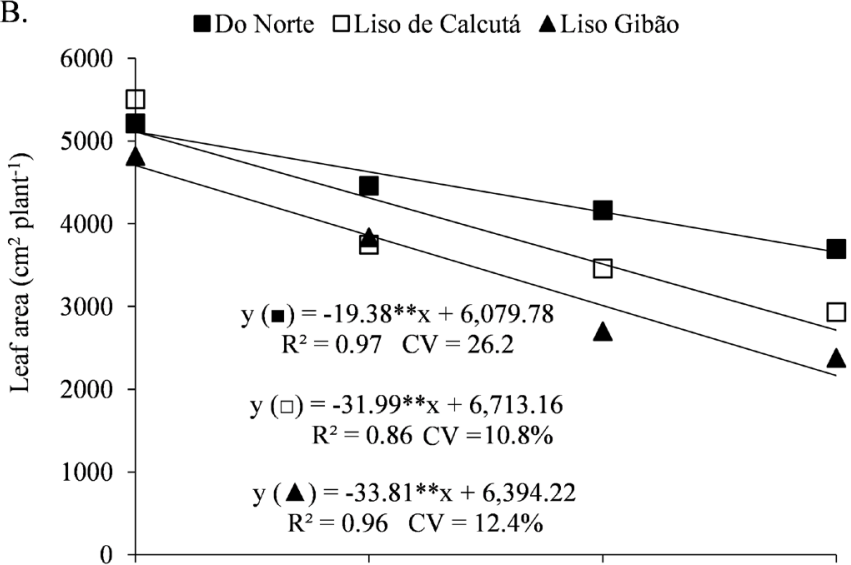

D.

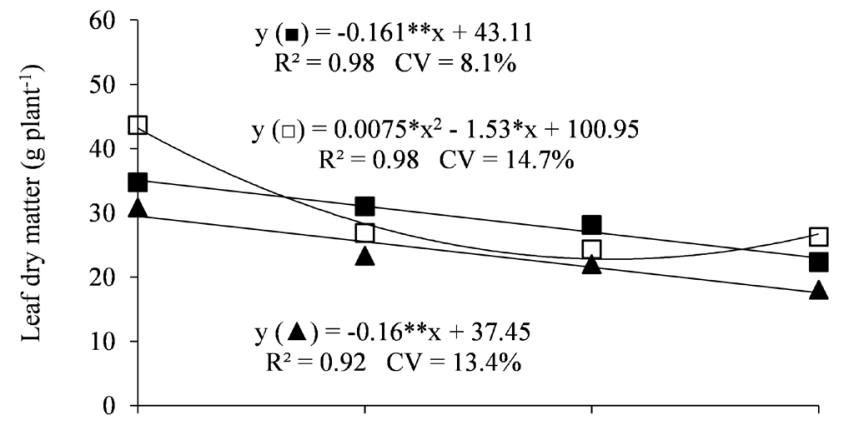

F.

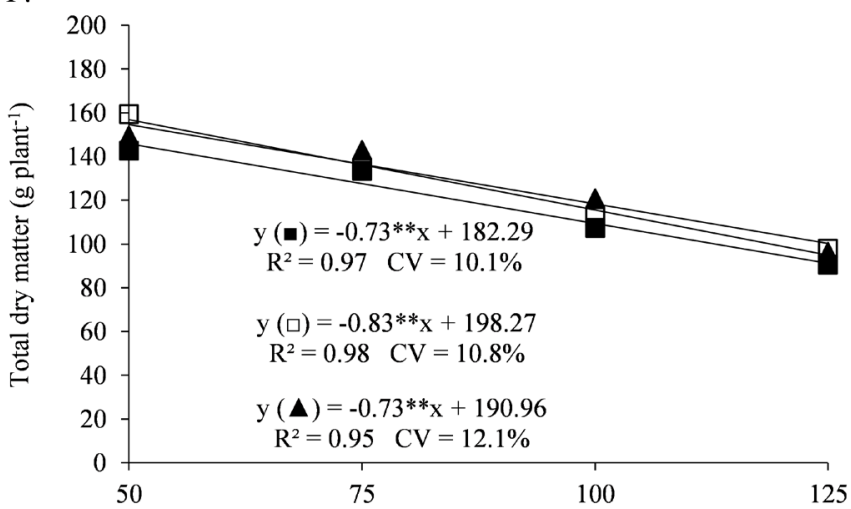

Concentration of the nutrient solution (\%)

ns, * and ${ }^{* *}$ - Not significant $(\mathrm{p}>0.05)$, significant at $\mathrm{p} \leq 0.05$ and $\mathrm{p} \leq 0.01$ by $\mathrm{F}$ test, respectively

Figure 1. Number of leaves (A), leaf area (AF), stem dry matter (C), leaves dry matter (D), fruit dry matter (E) and total dry matter $(F)$ of three cultivars of gherkins in coconut fiber fertigated with concentrations of nutrient solution

The reduction in the number of leaves observed in cv. Liso Gibão in the highest concentration probably occurred as an indirect effect of the electrical conductivity of the nutrient solution, a fact not observed for the other cultivars, which may be an indication that the cultivars Do Norte and Liso de Calcutá are more tolerant to salinity.
The leaf area of the plants was negatively affected by the increase in nutrient concentration in the nutrient solution for the three cultivars, according to the adjusted regression equations, linear reductions of $19.38,31.99$ and $33.81 \mathrm{~cm}^{2}$ plant ${ }^{-1}$ per unit increase of the concentration were observed, so that at the $125 \%$ concentration, reductions of $28.43 \%, 46.92 \%$ and $53.91 \%$ were 
obtained compared to the values at the lowest concentration, in the cultivars Do Norte, Liso de Calcutá and Liso Gibbon, respectively (Figure $1 \mathrm{~B}$ ).

The leaf area reduction of the three cultivars with the increasing concentration of nutrients, can be attributed to the increase in the electrical conductivity of the nutrient solution, confirming the results presented by Oliveira et al. (2012), who observed reduction of $7.1 \%$ in the leaf area of the gherkin when the plants were fertigated with a nutritive solution, $150 \%$ the concentration of nutrients proposed by Castellane \& Araujo (1994). This result may have occurred because the increase in the ionic concentration of the nutrient solution causes a decrease in the osmotic potential of the medium, requiring greater energy expenditure by plants for the absorption of water and nutrients, directly influencing cell division and protein synthesis, directly reflecting in the leaf area of plants (Taiz et al., 2017).

Regarding the stem dry matter (SDM), according to the regression equations adjusted for each cultivar, there was linear reduction of $0.22 \mathrm{~g}$ for cv. Do Norte (Figure 1C) with one percentage increase in the concentration of the nutrient solution, that is, when the plants were fertigated with a nutrient solution of $125 \%$ concentration $\left(31.40 \mathrm{~g} \mathrm{plant}^{-1}\right)$, there was a total reduction of $34.34 \%$ in relation to the dry matter obtained at $50 \%$ concentration $\left(47,83 \mathrm{~g} \mathrm{plant}^{-1}\right)$. For the cultivars Liso de Calcutá and Liso Gibão, better adjustment to the quadratic model was observed, with higher values being obtained for the concentrations $76.1 \%$ and $83.7 \%$, with 47.6 and 43.4 g plant $^{-1}$, respectively. It was also verified that in the most concentrated solution (125\%) the cultivars presented values of SDM 31.5 and 29.3 g plant $^{-1}$, respectively (Figure 1C).

The reduction in SDM which occurred at higher nutrients concentration is due to the effect of the higher electrical conductivity of the nutrient solution, which differs in part, from the results presented by Oliveira et al. (2012), who worked with gherkin, cv. Do Norte, using the nutrient solution recommended by Castellane \& Araújo (1994), there was no reduction in SDM when using concentrated nutrient solution up to $150 \%$. The higher accumulation of dry matter in the stem, mainly due to the increase in the number of secondary stems can contribute to the production of fruits in the gherkin, because the higher concentration of female flowers and, consequently, of fruits, occurs in the secondary or tertiary branches (Modolo \& Costa, 2003).

Regarding the dry matter of leaves (LDM), there was linear reduction in the cultivars Do Norte and Liso Gibão, with losses of 34.18 and $40.75 \%$, respectively (Figure 1D). For the cultivar Liso de Calcutá, there was a reduction in LDM up to $102 \%$ concentration, with little variation in the highest concentrations (Figure 1D). The reduction in LDM can be justified by the reduction in leaf size, mainly in the cultivar Liso Gibão, as can be seen for the variables: number of leaves (Figure 1A) and leaf area (Figure 1B). This result arises because plants are under conditions with low osmotic potential in the root zone, the increase in ionic concentration, reduces the absorption of water and nutrients by plants.

Analyzing the fruits dry matter (FDM), there was linear reduction with the increase in the concentration of nutrients in the nutrient solution of the three cultivars. According to the regression equations presented, there were reductions in the FDM of $0.35,0.46$ and 0.50 g plant $^{-1}$ with unit increase in nutritional concentration, resulting in total losses of $41.7 \%$, $48.4 \%$ and $43.5 \%$, for the cultivars Do Norte, Liso de Calcutá and Liso Gibão, respectively, with the application of $125 \%$ nutritional concentration (Figure 1E).

The significant reduction in FDM that occurred in plants fertigated with a more concentrated nutrient solution probably occurred due to the lower translocation of photoassimilates to the fruits in response to the salinity of the nutrient solution.

The total dry matter (TDM) was also negatively affected by the increase in the concentration of nutrients in the nutrient solution, in which the increase of a percentage unit of the ionic concentration caused reductions of $0.73,0.83$ and 0.73 g plant $^{-1}$, resulting in a total loss of $37.5,39.7$ and $35.3 \%$ in the most concentrated solution, respectively, for the cultivars Do Norte, Liso de Calcutá and Liso Gibão (Figure 1F).

In general, it was verified that in the three cultivars there was reduction in dry matter accumulation when the plants were fertigated with a more concentrated nutrient solution (125\%) which can be attributed to high electrical conductivity, confirming the results observed by other authors working with the gherkin, cv. Do Norte, cultivated in coconut fiber (Oliveira et al., 2012; 2014b), which verified that the application of nutrient solution of high concentration caused a reduction in biomatter accumulation.

The reduction in the accumulation of biomatter occurs because highly concentrated nutrient solutions cause a reduction in the osmotic potential of the cultivation medium, causing a reduction in the absorption of water and nutrients by the plants (Grattan \& Grieve, 1999).

It was verified that there was a similar response between the variables FDM and TDM, in which there was linear reduction with the increase in the concentration of nutrients in all cultivars, showing that the fruits can be considered preferential drains of photoassimilates in the gherkin crop (Oliveira et al., 2012).

The variables number of fruits (NF), fruit fresh weight (FFW) and fruit production (PROD) were affected by the interaction between cultivar factors and nutrient solutions, as well as by the factor nutrient solutions in isolation ( $\mathrm{p} \leq 0.01$ ). Regarding the isolated effect of the cultivars, there was a significant response for all variables, being at the level of $\mathrm{p} \leq 0.01$ for NF and FFW, and $\mathrm{p} \leq 0.05$ for PROD (Table 3).

The cv. Liso Gibão was higher for the variables: number of fruits and fruit production, although it did not differ from the cv. Liso de Calcutá for fruit production. For the fruit fresh weight, the highest values were obtained in the cultivars Liso

Table 3. Summary of the analysis of variance for number of fruits (NF), fruit fresh weight (FFW) and fruit productivity (PROD) in cultivars of gherkin fertigated with nutrient solutions of different concentrations

\begin{tabular}{|c|c|c|c|c|}
\hline \multirow{2}{*}{$\begin{array}{l}\text { Sources } \\
\text { of variation }\end{array}$} & \multirow{2}{*}{ DF } & \multicolumn{3}{|c|}{ Mean squares } \\
\hline & & NF & FFW & PROD \\
\hline Cultivars (C) & 2 & $246.08^{* *}$ & $652.79 * *$ & $19,638.80^{*}$ \\
\hline Nutritional solution (SN) & 3 & $130.14^{\star *}$ & $179.34^{\star *}$ & $208,692.53^{* *}$ \\
\hline $\mathrm{C} \times \mathrm{SN}$ & 6 & $32.18^{* *}$ & $175.08^{* *}$ & $17,414.79^{*}$ \\
\hline Block & 2 & $5.10^{\mathrm{ns}}$ & $16.59 \mathrm{~ns}$ & $8,345.15^{\text {ns }}$ \\
\hline Residue & 22 & 5.97 & 22.30 & $4,918.93$ \\
\hline CV (\%) & & 14.92 & 17.51 & 20.83 \\
\hline
\end{tabular}

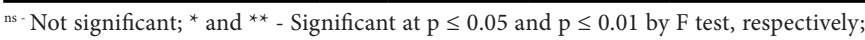
$\mathrm{CV}$ - Coefficient of variation; DF - Degrees of freedom 
Table 4. Mean values of number of fruits (NF), fruit fresh weight (FFW) and fruit productivity (PROD) in fertigated gherkin cultivars with nutrient solutions of different concentrations

\begin{tabular}{llll}
\hline \multicolumn{1}{c}{ Cultivars } & $\begin{array}{c}\text { NF } \\
\text { (unit) }\end{array}$ & $\begin{array}{c}\text { FFW } \\
\text { (g fruit }^{-1} \text { ) }\end{array}$ & $\begin{array}{c}\text { PROD } \\
\text { (g plant }^{-1} \text { ) }\end{array}$ \\
Do Norte & $13.97 \mathrm{~b}$ & $29.30 \mathrm{ab}$ & $409.40 \mathrm{~b}$ \\
Liso de Calcutá & $13.15 \mathrm{~b}$ & $35.99 \mathrm{a}$ & $473.38 \mathrm{ab}$ \\
Liso Gibão & $21.59 \mathrm{a}$ & $25.11 \mathrm{~b}$ & $542.19 \mathrm{a}$ \\
\hline
\end{tabular}

Means followed by the same letter in the column do not differ significantly by the Tukey test at $\mathrm{p} \leq 0.05$

de Calcutá and Do Norte, although the latter did not differ significantly from the cv. Liso Gibão (Table 4).

In general, it has been verified that cultivars which produce smooth fruits (without spikes) have larger fruits, resulting in greater yield. In addition, it was found that the highest fruit production obtained in cv. Liso Gibão was due to the greater number of fruits, since it presented smaller fruits, a fact that has also been observed by other authors (Gomes et al., 2015; Oliveira et al., 2015; Morais et al., 2018).

According to regression analysis, it was verified that the cultivars Do Norte and Liso de Calcutá had linear reduction in the number of fruits per plant (NF). The highest values were obtained at the concentration of $50 \%$, with 19.7 and 17.8 fruits plant ${ }^{-1}$, presenting linear reduction with the increase in nutrient concentration in the nutrient solution, so that in plants fertigated with more concentrated nutrient solution (125\%), there were reductions of 57.9 and $52.4 \%$, respectively. For cv. Liso Gibão, the data were better adjusted to the quadratic model, with the highest NF obtained at the concentration of $76.3 \%$ ( 25.2 fruits), representing an increase of $12.2 \%$ in relation to the NF observed at 50\% concentration (22.4 fruits). It was also verified that the increase in nutrient concentration caused a reduction in NF, so that at the $125 \%$ concentration, 15,8 fruits were obtained (Figure 2A).

The cv. Liso Gibão is characterized by having little vegetative development (Topseed $\left.{ }^{\circ}\right)$, thus, the effect of the increase in nutrient concentration up to $76.3 \%$ favored fruit setting, although it also caused reduction in vegetative growth.

The reduction in the number of fruits under conditions of high concentration of nutrient solution is due to the high rate of abortion of flowers and fruits, caused by the reduction in the transport of soluble carbohydrates from the leaves to the flowers, thus reducing pollen viability (Ghanem et al., 2009). This fact was also observed in works developed with the cultivation of melon (Melo et al., 2011; Terceiro Neto et al., 2013) and cucumber (Oliveira et al., 2017).

The increase in the concentration of the nutrient solution did not affect fruit fresh weight in the cultivars Do Norte and Liso de Calcutá, obtaining an average weight of 28.8 and $35.7 \mathrm{~g}$ fruit $^{-1}$, respectively (Figure $2 \mathrm{~B}$ ). According to the seed producer (Feltrin ${ }^{\circ}$ ), these cultivars have an fruit fresh weight of 15 and $75 \mathrm{~g}_{\text {fruit }}{ }^{-1}$, respectively. Thus, it was verified that the fruits obtained in the present study were higher for cv. Do Norte, and smaller to the cv. Liso de Calcutá, compared to the values indicated by the company. However, they are close to the values obtained in other studies developed in the same region in which the present study was carried out (Oliveira et al., 2014a; 2015; Gomes et al., 2015).
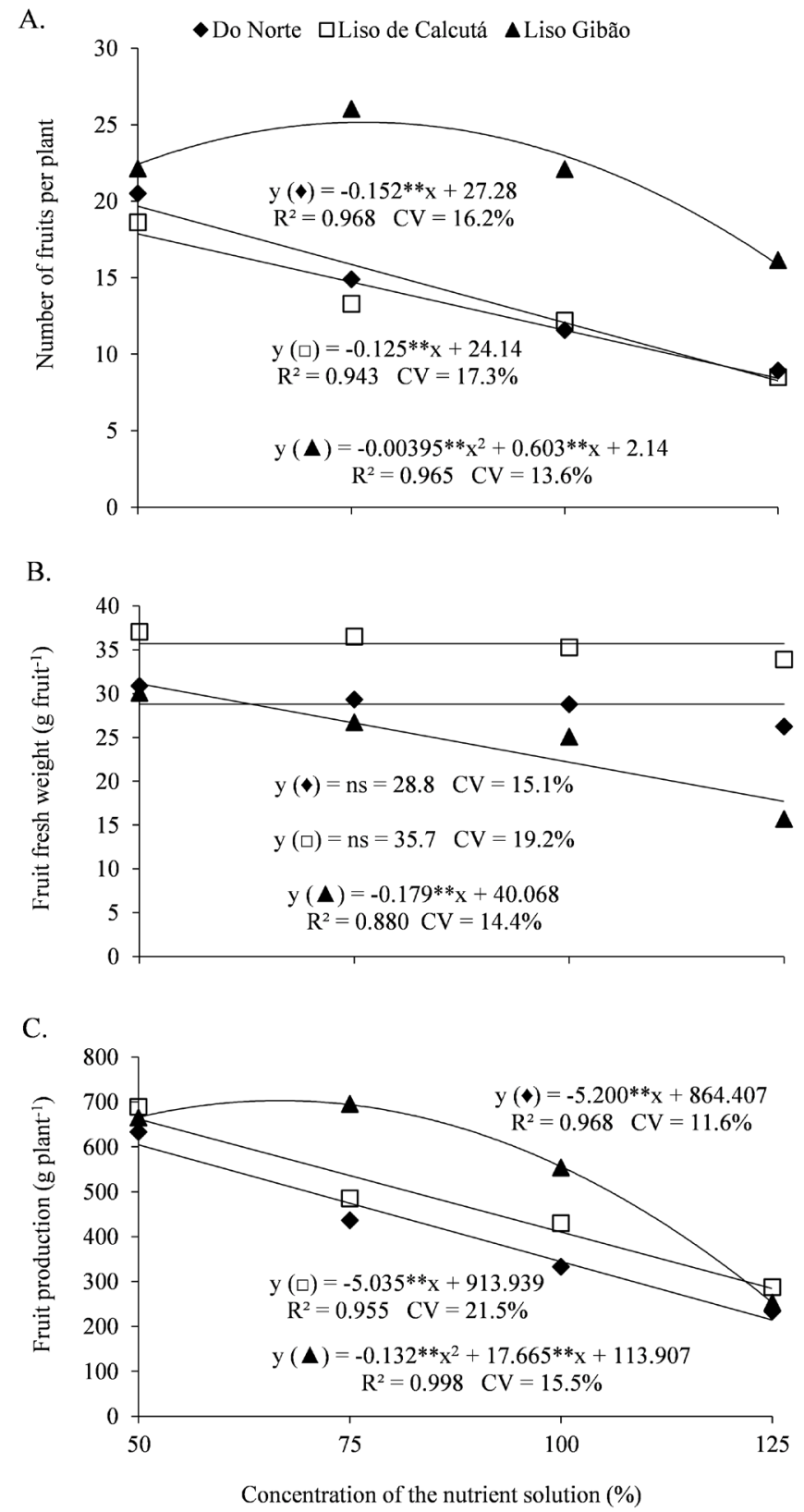

ns, ${ }^{*}$ and ${ }^{* *}$ - Not significant ( $\left.\mathrm{p}>0.05\right)$, significant at $\mathrm{p} \leq 0.05$ and $\mathrm{p} \leq 0.01$ by F test, respectively

Figure 2. Number of fruits (A), fresh fruit matter (B) and fruit productivity $(\mathrm{C})$ of three cultivars of gherkins in coconut fiber fertigated with concentrations of nutrient solution

On the other hand, the fruit fresh weight of the cultivar Liso Gibão was reduced linearly with the increase in nutrient concentration, reducing from $31.1 \mathrm{~g}$ fruit $^{-1}(50 \%)$ to $17.7 \mathrm{~g}$ fruit $^{-1}(125 \%)$, corresponding to a total reduction of $43.1 \%$ (Figure 2B).

Thus, it was verified that the effect of the high concentration of the nutrient solution was more evident in the setting than on the fruit fresh weight. According to Melo et al. (2011), this result is justified because the reduction in the number of fruits promotes greater development of the remaining fruits, justifying from then on, the lesser effect of salinity on the fruit fresh weight due to less competition between the fruits for the accumulation of photoassimilates.

Regarding fruit production, the results were similar to those observed for NF, recording a linear reduction with the increase 
of nutrient concentration in the cultivars Do Norte and Liso de Calcutá, and quadratic adjustment for the cultivar Liso Gibão. For Do Norte and Liso de Calcutá, the highest yields were obtained at the concentration of $50 \%$, obtaining 634.4 and 662.2 g plant $^{-1}$, respectively. However, the increase in nutrient concentration in the nutrient solution caused a linear reduction in fruit production, so that at the $125 \%$ concentration, there were reductions of 61.5 and 57.0\%, respectively (Figure 2C).

On the other hand, the highest fruit production in the cultivar Liso Gibão occurred at the concentration of $66.9 \%$ (704.9 g plant $\left.^{-1}\right)$ and decreased from this concentration, so that at the highest level (125\%) the lowest yield was observed, obtaining 259.5 g plant $^{-1}$ (Figure 2C). Therefore, it was verified that the effect of the high concentration of the nutrient solution on fruit production (Figure $2 \mathrm{C}$ ) is directly related to the number of fruits per plant.

In general, it appears that plants fertigated with less concentrated nutrient solution performed better, which may indicate that plants grown in coconut fiber have less nutrient requirements than melon. Another hypothesis is that in substrate cultivation the roots are kept continuously under adequate humidity conditions, while in the NFT system (Nutrient Film Technique), in the period between two consecutive nutrient solution recirculation, it can provide a more intense osmotic effect than in substrate cultivation (Rodríguez-Ortega et al., 2019).

These results confirm those presented by Cosme et al. (2018), who, working with Gália melon cultivated in coconut fiber, also obtained greater development and crop yield using nutrient solution diluted by $50 \%$. This fact was also confirmed by Silva et al. (2017) working with Gália melon, as well as by Diniz et al. (2015) with the cultivation of cucumber.

Another probable reason for the reduction in growth and yield of the cultivars studied in the highest concentrations of nutrients in the nutrient solution can be attributed to the increase in the electrical conductivity of the solution, decreasing the osmotic potential of the medium. With this, inhibition of plant growth and photosynthesis, and excessive ion accumulation can occur, causing toxicity, inhibition of cell division and protein synthesis (Taiz et al., 2017).

\section{Conclusions}

1. The cultivar Liso Gibão stood out for having higher number of fruits, while the cultivar Liso de Calcutá produces heavier fruits.

2. In order to obtain the highest fruit yield of the gherkin cultivated in coconut fiber, fertigations must be carried out using nutrient solution diluted in 50\% for the cultivars Do Norte and Liso de Calcutá, while for cv. Liso Gibão it is recommended the nutrient solution diluted in $75 \%$ of the concentration of nutrients recommended for the cultivation of melon.

\section{Literature Cited}

Alvares, C. A.; Stape, J. L.; Sentelhas, P. C.; Gonçalves, J. L. de M.; Sparovek, G. Koppen's climate classification map for Brazil. Meteorologische Zeitschrift, v. 22, p.711-728, 2013. http://dx.doi. org/10.1127/0941-2948/2013/0507
Castellane, P. D.; Araújo, J. A. C. Cultivo sem solo - hidroponia. Jaboticabal: FUNEP/UNESP, 1994. 43p.

Cosme, C. R.; Dias, N. da S.; Silva, K. M. P.; Fanteles, J. L. V.; Gurgel, M. T.; Fernandes, C. dos S. Growth of melon cultivated in coconut fiber under different concentrations of nutrient solution. Comunicata Scientiae, v.9, p.381-392, 2018. http://dx.doi. org/10.14295/CS.v9i3.2736

Diniz, A. A.; Dias, N. da S.; Souza, F. I. de; Souza, A. C. M.; Mesquita, F. O.; Souza, F. I. de. Efeito da solução nutritiva sob o crescimento e composição mineral em pepino cultivado em substrato de fibra de coco. Semina: Ciências Agrárias, v.36, p.3043-3054, 2015. http:// dx.doi.org/10.1590/S0102-05362008000300011

Duarte, T. da S.; Peil, R. M. N.; Bacchis, S.; Strassburger, A. S. Efeito da carga de frutos e concentrações salinas no crescimento do meloeiro cultivado em substrato. Horticultura Brasileira, v.26, p.348-353, 2008. http://dx.doi.org/10.1590/S010205362008000300011

Ferreira, D. F. Sisvar: a guide for its bootstrap procedures in multiple comparisons. Ciência e Agrotecnolgia, v.38, p.109-112, 2014. https://doi.org/10.1590/S1413-70542014000200001

Furlani, P. R.; Silveira, L. C. P.; Bolonhezi, D.; Faquim, V. Cultivo hidropônico de plantas. Campinas: Instituto Agronômico de Campinas, 1999. 52p. Boletim Técnico, 180

Ghanem, M. E.; Elteren, J. van; Albacete, A.; Quinet, M.; MartínezAndújar, C.; Kinet, J. M.; Pérez-Alfocea, F.; Lutts, S. Impact of salinity on early reproductive physiology of tomato (Solanum lycopersicum) in relation to a heterogeneous distribution of toxic ions in flowers organs. Functional Plant Biology, v.36, p.125-136, 2009. https://doi.org/10.1071/FP08256

Grattan, S. R.; Grieve, C. M. Salinity-mineral nutrient relations in horticultural crops. Scientia Horticulturae, v.78, p.127-157, 1999. https://doi.org/10.1016/S0304-4238(98)00192-7

Gomes, L. P.; Oliveira, F. de A. de; Bezerra, F. M. S.; Lima, L. A.; Costa, L. P.; Guedes, R. A. A. Produtividade de cultivares de maxixeiro em função de doses de biofertilizante. Revista Agro@mbiente On-line, v.9, p.275-283, 2015. https://doi.org/10.18227/19828470ragro.v9i3.2381

Melo, T. K. de; Medeiros, J. F. de; Espínola Sobrinho, J.; Figueirêdo, V. B.; Pereira, V. da C.; Campos, M. de S. Evapotranspiração e produção do melão Gália irrigado com água de diferentes salinidades e adubação nitrogenada. Revista Brasileira de Engenharia Agrícola e Ambiental, v.15, p.1235-1242, 2011. http:// dx.doi.org/10.1590/S1415-43662011001200004

Modolo, V. A.; Costa, C. P. da. Avaliação de linhagens de maxixe paulista cultivadas em canteiros com cobertura de polietileno. Horticultura Brasileira, v.21, p.534-538, 2003. http://dx.doi. org/10.1590/S0102-05362003000300024.

Morais, D. L.; Aroucha, E. M. M.; Oliveira, F. de A. de; Medeiros, J. F. de; Paiva, C. A. de; Nascimento, L. V. Impact of salinity on quality and post-harvest conservation of gherkin (Cucumis anguria L.). Journal of Agricultural Science, v.10, p.167-177, 2018. https://doi. org/10.5539/jas.v10n4p167

Oliveira, A. P. de; Silva, O. P. R. da; Bandeira, N. V. da S.; Silva, D. F. da; Silva, J. A.; Pinheiro, S. M. G. Rendimento de maxixe em solo arenoso em função de doses de esterco bovino e biofertilizante. Revista Brasileira de Engenharia Agrícola e Ambiental, v.18, p.1130-1135, 2014a. http://dx.doi.org/10.1590/1807-1929/ agriambi.v18n11p1130-1135 
Oliveira, F. de A. de; Oliveira, M. K. T. de; Lima, L. A.; Bezerra, F. M. S.; Alves, R. de C.; Linhares, P. S. F. Fertirrigação nitrogenada em cultivares de maxixeiro cultivadas em substrato de fibra de coco. Irriga, v.20, p.388-400, 2015. DOI: https://doi.org/10.15809/ irriga.2015v20n2p388

Oliveira, F. de A. de; Oliveira, M. K. T. de; Medeiros, J. F. de; Silva, O. M. dos P. da; Paiva, E. P. de; Maia, P. M. E. Produtividade do maxixeiro cultivado em substrato e fertirrigado com soluções nutritivas. Horticultura Brasileira, v.32, p.464-467, 2014b. http:// dx.doi.org/10.1590/S0102-053620140000400015

Oliveira, F. de A. de; Oliveira, M. K. T. de; Silva, O. M. dos P. da; Maia, P. M. E.; Paiva, E. P. de; Silva Júnior, J. G. da. Desenvolvimento do maxixeiro cultivado em substrato fertirrigado com diferentes soluções nutritivas. Revista Brasileira de Ciências Agrárias, v.7, p.777-783, 2012. http://dx.doi.org/10.5039/agraria.v7isa2014

Oliveira, F. de A. de; Souza Neta, M. L. de; Miranda, N. de O.; Souza, A. A. T.; Oliveira, M. K. T. de; Silva, D. D. A. da. Strategies of fertigation with saline water for growing cucumber in a greenhouse. Revista Brasileira de Engenharia Agrícola e Ambiental, v.21, p.606-610, 2017. http://dx.doi.org/10.1590/18071929/agriambi.v21n9p606-610

Portela, I. P.; Peil, R. M. N.; Rombaldi, C. V. Efeito da concentração de nutrientes no crescimento, produtividade e qualidade de morangos em hidroponia. Horticultura Brasileira, v.30, p.266273, 2012. http://dx.doi.org/10.1590/S0102-05362012000200014

Rodríguez-Ortega, W. M.; Martínez, V.; Nieves, M.; Simón, I.; Lidón, V.; Fernandez-Zapata, J. C.; Martinez-Nicolas, J. J.; CámaraZapata, J. M.; García-Sánchez, F. Agricultural and physiological responses of tomato plants grown in different soilless culture systems with saline water under greenhouse conditions, Scientific Reports, v.9, p.6733, 2019. http://dx.doi.org/10.1038/s41598019-42805-7
Silveira, P. T. de S.; Normane, M. C. S. da; Reis, M. F. T.; Landin, L. B.; Aquino, A. A. de. Qualidade pós-colheita do maxixe (Cucumis anguria L.) revestido com amido de milho adicionado do extrato de própolis. Revista Brasileira de Tecnologia Agroindustrial, v.9, p.1888-1899, 2015. http://dx.doi.org/10.3895/rbta.v9n2.1953.

Strassburger, A.S.; Peil, R. M.N.; Fonseca, L. A. da; Aumonde, T.Z. Crescimento e produtividade da abobrinha italiana: Efeito da concentração iônica da solução nutritiva. Seminas: Ciências Agrárias, v.32, p.553-564, 2011. https://doi.org/10.5433/1679-0359.2011v32n2p553

Silva, K. M. P.; Cosme, C. R.; Dias, N. da S.; Queiroz, I. S. R. de; Diniz, A. A.; Santos Júnior, J. A. Produção e qualidade de frutos do meloeiro cultivado em sistema semi-hidropônico. Revista Brasileira de Agricultura Irrigada, v.11, p.1914-1923, 2017. http:// dx.doi.org/10.7127/rbai.v11n600653

Souza, M. S. de; Alves, S. S. V.; Dombroski, J. L. D.; Freitas, J. D. B. de; Aroucha, E. M. M, Comparação de métodos de mensuração de área foliar para a cultura da melancia. Pesquisa Agropecuária Tropical, v.42, p.241-245, 2012. http://dx.doi.org/10.1590/S1983-40632012000200016 Souza Neta, M. de L.; Oliveira, F. de A. de; Torres, S. B.; Souza, A. A. T.; Silva, D. D. A. da; Santos, S. T. dos. Gherkin cultivation in saline medium using seeds treated with a biostimulant. Acta Scientiarum. Agronomy, v.40, p.1-10, 2018. http://dx.doi. org/10.4025/actasciagron.v40i1.35216

Taiz, L.; Zeiger, E.; Møller, I.; Murphy, A. Fisiologia e desenvolvimento vegetal. 6.ed. Porto Alegre: Artmed, 2017. 888 p.

Terceiro Neto, C. P. C.; Gheyi, H. R.; Medeiros, J. F. de; Dias, N. da S.; Campos, M. de S.; Produtividade e qualidade de melão sob manejo com água de salinidade crescente. Pesquisa Agropecuária Tropical, v.43, p.354-362, 2013. http://dx.doi.org/10.1590/S1983-40632013000400007

Thiruvengadam, M.; Chung, I. Phenolic compound production and biological activities from in vitro regenerated plants of gherkin (Cucumis anguria L.). Electronic Journal of Biotechnology, v.18, p.295-301, 2015. https://doi.org/10.1016/j.ejbt.2015.05.005 